\title{
POST MEDIA LITERACY: SUATU UPAYA PEMBERDAYAAN HIDUP DITENGAH DUNIA YANG SESAK MEDIA
}

\author{
Khairin Nizomi ${ }^{1}$ \\ ${ }^{1}$ Mahasiswa Magister Ilmu Perpustakaan Dan Informasi UIN Sunan Kalijaga Yogjakarta \\ khairinnizomi93@gmail.com
}

\begin{abstract}
Sekarang manusia hidup dalam abad komunikasi massa kehidupan manusia sekarang tak bisa dilepaskan dari media mssa. Keluhan tentang dampak media massa kerap terdengar. Untuk itu perlu kiranya memahami apa itu literasi media. Pemahaman ini penting bagi para pegiat pendidikan melek media agar mampu melakukan kritik terhdap berbagai media yang melanggar aturan dan etika media yang ada di Indonesia sehingga terhindar dari berita yang bohong (hoax). Metode yang digunakan dalam penelitian ini adalah deskriptif kualitatif, dengan jenis penelitian studi kasus pada media social (Facebook). Analisis data dalam penelitian ini menggunakan Teori Narartive Analysis. Teknik pengumpulan data dalam penelitian ini menggunakan studi dokumen dan teknik pengambilan sampel menggunakan Proposive Sampling. Hasil dari dari penelitian ini menunjukkan Literasi media sama sekali bukanlah gerakan anti-media. Justru merupakan tindakan yang kita lakukan untuk menjaga media agar tetap bisa menjalankan fungsinya di tengah masyarakat. Dengan melek media, media massa akan memiliki khalayak bukan konsumen yang pada gilirannya akan memengaruhi bagaimana seharusnya media menjalankan peranya. Bila media tetap memperlakukan khalayak sebagai konsumen maka media akan mendapat tekanan dari khalayak.
\end{abstract}

Kata Kunci: Pos, Media Literacy, Upaya Pemberdayaan, Dunia Yang Sesak Media

\section{ABSTRACT}

Now humans live in the mass communication age of human life now can't be separated from the mass media. Complaints about the impact of the mass media are often heard. For that, it is necessary to understand what is media literacy. This understanding is important for media literacy education activists to be able to criticize the media who violate the rules and ethics of the media in Indonesia, so avoid that false news (hoaxes). The method used in this study is descriptive qualitative, with the type of case study research on social media. Analysis of the data in this study using the Narrative Analysis Theory. Data collection techniques in this study using document studies and sampling techniques using Purposive Sampling. The results of this study indicate that media literacy is by no means an anti-media movement. It is precisely the action we take to keep the media to stay functional in society. With media literacy, mass media will have the audience, not the consumer who in turn would affect how the media should carry out its role. If the media still treats the audience as a consumer, then the media will get pressure from the audience. Then to literacy truth of a media (news) could see how the narrative (status) is growing.

Key Word: Post, Media Literacy, Empowerment Effort, World's Most Crowded Media 



\section{PENDAHULUAN}

Setelah terjadi perubahan tatanan politik di Indonesia, yang populer dengan sebutan reformasi, dunia media masa mengalami perubahan mendasar. Bukan hanya terjadi peningkatan jumlah media massa (cetak dan elektronik) melaikan juga terjadi perubahan sifat dan keragaman isi media massa secara kualitatif. Iklan kebebasan pers atau kebebasan medialah yang memungkinkan terjadinya perubahan mendasar itu. Pada era reformasi, Indonesia menjadi salah satu negara yang indutri media masanya berkembang dengan pesat (Iriantara, 2009: 45).

Perkembangan dan pertambahan media masa di Indonesia bisa dilihat dari meningkatnya jumlah stasiun televisi yang mengudara secara nasional yang hampir dua kali lipat. Pada masa Orede Baru, kita hanya mengenal TVRI, yang kemudian disusul di akhir Orde Baru dan setelah reformasi bertumbuhan stasiun swasta antara lain, RCTI, SCTV, ANTV, Indosiar, TV One (sebelumnya berama Lativi), Global Tv, Mettro TV, Tras TV, Trans 7, Kompas TV, serta berbagai stasiun televisi di daerah (Rochinah \& junaedi, 2013: 3).

Sedangkan stasiun radio swasta nasional yang tadinya hanya mengudara secara lokal, beberapa kini mengudara secara nasional melalui satelit sehingga dinamakan radio satelit sehingga dinamakan radio satelit, seperti Prambors dengan Radio-Net nya. Beberapa stasiun radio membentuk jaringan sehingga satu stasiun radio siarannya dapat diterima di beberapa kota seperti Radio Elshinta. Tercatat ada 803 stasiun radio milik pemerintah dan swasta yang mengudara di Indonesia, yang terdiri atas 678 stasiun radio yang menggudara di jalur AM, 43 di jalur FM dan 82 dijalur SW. Namun tidak diperoleh data untuk radio komunikasi yang ada di seluruh Indonesia (Iriantara, 2009: 46).

Adapun untuk media cetak, jumlah media cetak yang terbit di Indonesia tak bisa diketahui dengan pasti. Menginggat banyaknya media cetak (koran harian, majalah dan tabloid) yang terbitannya tidak teratur atau hanya sekali dua kali terbit. Kendala ini terjadi karena setelah era reformasi media cetak tidak lagi memerlukan izin terbit. Cukup mendaftarkan perusahaan-perusahaan yang bergerak dalam bidang usaha non-pres (Iriantara, 2009: 46).

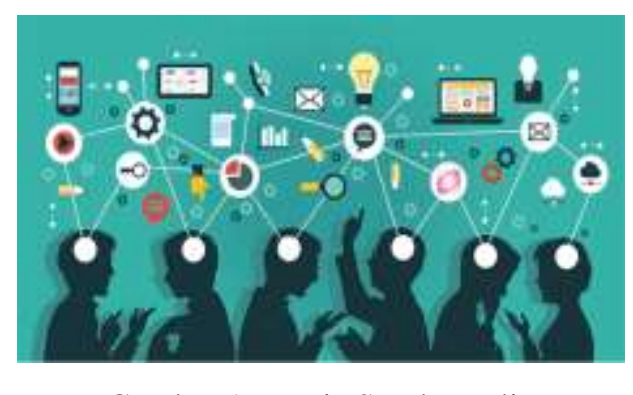

Gambar 1: Dunia Sesak Media 
Sehingga perkembangan tersebut mengubah Mediascape Indonesia kemudian membawa masyarakat Indonesia menjadi masyarakat yang hidup dalam apa yang biasa diistilahkan sebagai "dunia sesak-media" (media-saturated world). Media massa berubah dari "media perjuangan" menjadi "media komersial". Artinya media massa memulai proses menggeser khalayaknya dari public atau warga negara menjadi konsumen semata. Proses pergeseran itu mungkin bukan dilakukan secara senghaja melaikan karena proses perkembangan belaka, namun konsekuensinya sangat besar bagi khalayak media.

Perkembangan media komersial yang seperti itu, menurut Henry Subiakto, menerapkan khalayak menjadi konsumen (consumers) dan bukan sebagai warga negara (Citizens). Tujuan media komersial adalah menghasilkan keuntungan bagi pemilik dan pemegang saham, dan bukan mendorong mengembangkan warga negara yang aktif. Konsekuensinya dari perkembangan tersebut, media komersial mendorong khalayaknya "menikmati dirinya sendiri dan membeli produk, sehingga media massa menyajikan apa yang laku atau populer di masyarakat tanpa mempedulikan apakah hal tersebut melecehkan logika, mengacak-acak budaya, menupulkan hati nurani, atau mengabaikan kepentingan public (Iriantara, 2009: 47).

Menginggat media masa memiliki pengaruh terhadap kehidupan social satu kelompok masyarakat dan hanya menempatkan public sebagai konsumen. Karena itu perlu kiranya melaksanakan Pendidikan melek media. Pemahaman ini penting bagi para pegiat pendidikan melek media agar mampu melakukan kritik terhdap berbagai media yang melanggar aturan dan etika media yang ada di Indonesia. Sehingga terhindar dari pemberitaan bohong (hoax) di dunia yang sesak media ini.

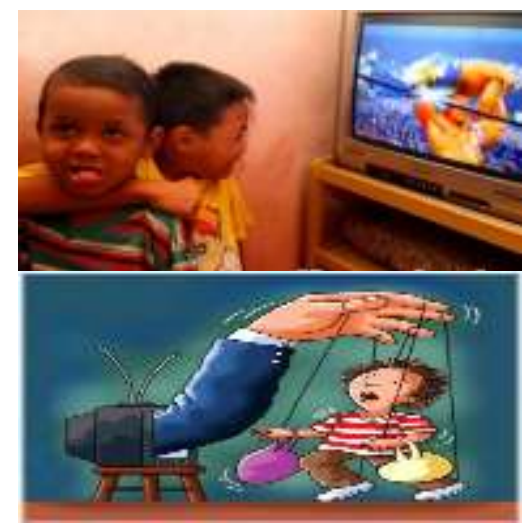

Gambar 2: Pengaruh Media

Berdasarkan fakta di atas, permasalahan dalam penelitian ini merumuskan tentang:

1. Bagaimana Literasi Media Dapat Memberdayakan Khalayak?

2. Bagaimana Melek Kebenaran Suatu Berita? 


\section{KERANGKA TEORITIS}

1. Analisi Naratif

Salah satu teknik yang bisa digunakan dalam melihat fenomena di media social (postinag/status) adalah dengan menggunakan analisis naratif. Analisi naratif melihat teks berita sebuah cerita, sebuah dongeng. Di dalam cerita ada plot, adegan, tokoh dan karakter. Narasi naratif adalah analisis mengenai narasi, baik narasi fiksi (novel, puisi, cerita rakyat, dongeng, flim, komik, music, dan sebagainya), atau fakta berita yang masih memerlukan pembuktian. Menggunakan analisis naratif berarti menempatkan teks sebagai rangkaian peristiawa, logika, dan tata urutan peristiwa, bagian dari peristiwa yang dibuang (Erianto, 2013: 9). Yang bisa di artikan sebagai upaya penghitungan (recounting) atau pembacaan kembali terhadap dua atau lebih situasi yang secara logika terhubung, baik dari segi waktu maupun tempat, dan terkait dengan kosistensi sebuah subjek dari keseluruhan teks atau pesan untuk melihat narasi atau perubahan cerita dari tanda termasuk untuk mengungkap makna tersebunyi dari tanda (postinga). Naratif menekankan pada peranan bentuk tanda (actant) yang pada sebuah status diwakili oleh sosok tokoh utama dalam transisi makna. Bahwa tokoh utama tersebut memiliki peran terhadap bagaimana narasi itu berjalan (Nasrullah, 2013: 225).

\section{Mengapa Analisi Naratif Dan Pendekatan Sosial Foucault}

Analisis naratif memungkinkan kita menyelidiki hal-hal yang tersembunyi dan laten dari suatu berita atau postingan suatu teks media. Peristiwa disajikan dalam bentuk berita dan dalam cerita atau status sebenarnya terdapat nilai-nilai dan ideologi yang ingin ditonjolkan oleh pembuat beita. Pilihan peristiwa, pengambaran atas karakter, pilihan mana yang ditempatkan sebagai musuh dan pahlawan, dan nilai-nilai mana yang didukung memperlihatkan makna yang tersembunyi yang ingin ditekankan dari pembuat berita. Analisis naratif membantu kita untuk mengerti keberpihakan, ideologi dan kebenaran suatu berita dari pembuat berita. Lewat susunan peristiawa, karakter, dan unsur-unsur narasi kita bisa memahami makna yang ingin dikemukankan oleh pembuat berita (Erianto, 2013: 10).

Kemudian analisis naratif tersebut menjadi Berbunyi ketika di lengkapi dengan pendekatan faucault yang membukakan mata kita bahwa kekuasaan atau power yang bermain dalam proses pembentukan subjektivitas yang dimiliki oleh induvidu. Kekuasaan ini dengan energinya, dengan material yang 
dimilikinya, dengan interest atau tujuan diinginkannya telah mendikte cara-cara induvidu atau manusia lain untuk bertindak dan berprilaku dalam pranpranyya di masyarakat. Termasuk pada gilirannya, bahasa, ucapan, percakapan, dan tulisan atau teks yang kita hasilkan (Ida, 2014: 113). Persfektif inilah yang menghatarkan dilektika kekuasaan dan pengetahuan media massa sebagai post media literasi (Syahputra, 2013: 176).

\section{Memahami Apa Itu Literasi Media}

a. Literasi

Mulanya istilah literasi merujuk pada huruf, sehigga terkadang literasi diterjemahkan sebagai keaksaraan. Ini sesuai dengan makna harfiah bahwa literasi adalah kemampuan membaca menulis, bedarsarkan istilah itu, orang yang tidak bisa membaca disebut orang yang ilitisari atau diterjrmahkan buta aksara. Karena literasi pada dasarnya berkenaan dengan keaksaraan, orang memiliki kemampuan membaca dan menulis disebut orang melek aksara atau melek huruf (Iriantara, 2009: 3).

Ada beberapa defenisis tentang istilah literasi:

National Institute for Literacy, mendefinisikan Literasi sebagai "kemampuan individu untuk membaca, menulis, berbicara, menghitung dan memecahkan masalah pada tingkat keahlian yang diperlukan dalam pekerjaan, keluarga dan masyarakat." Definisi ini memaknai Literasi dari perspektif yang lebih kontekstual. Dari definisi ini terkandung makna bahwa definisi Literasi tergantung pada keterampilan yang dibutuhkan dalam lingkungan tertentu.

Education Development Center (EDC) menyatakan bahwa Literasi lebih dari sekedar kemampuan baca tulis. Namun lebih dari itu, Literasi adalah kemampuan individu untuk menggunakan segenap potensi dan skill yang dimiliki dalam hidupnya. Dengan pemahaman bahwa literasi mencakup kemampuan membaca kata dan membaca dunia.

Menurut UNESCO, pemahaman orang tentang makna literasi sangat dipengaruhi oleh penelitian akademik, institusi, konteks nasional, nilai-nilai budaya, dan juga pengalaman. Pemahaman yang paling umum dari literasi adalah seperangkat keterampilan nyata - khususnya keterampilan kognitif membaca dan menulis - yang terlepas dari konteks di mana keterampilan itu diperoleh dan dari siapa memperolehnya (Dunia Kampus, https://www.dkampus.com).

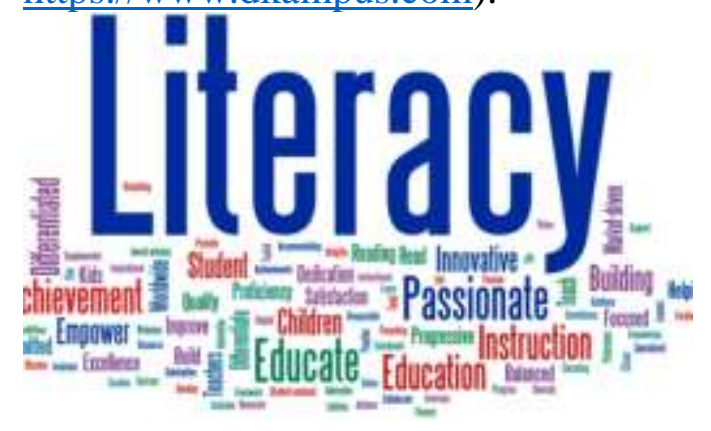

Gambar 3: Literasi

Dalam perkembangan selanjutnya, istilah literasi ini dipegunakan secara longgar dan meluas, bukan hanya berkenaan dengan kemampuan membaca dan menulis saja. Bukan juga hanya berkenaan dengan teks, hingga sekarang kita mengenal istilah literasi informasi, literasi media, literasi televesi atau bisa 
juga secara populer dinyatakan sebagai melek informasi, melek media dan melek televisi (Iriantara, 2009: 4).

b. Media

Secara umum dapat dipahami bahwa istilah "media" mencakup sarana komunikasi seperti pers, media penyiaran (broadcasting) dan senema (Burton, 1999: 9). Adapun menurut KBBI (Kamus Besar Bahasa Indonesia), bahwa media dapat diartikan sebagai: (1) alat, dan (2) alat atau sarana komunikasi seperti majalah, radio, televisi, film, poster, dan spanduk.

Menerut Association For Education And Communication Technologi (AECT) mendefenisikan media yaitu segala bentuk yang dipergunakan untuk suatu proses penyaluran informasi.

Sedangkan menurut Education Association mendefenisikan sebagai benda yang dapat dimanipulasikan, dilihat, didengar, dibaca atau dibicarakan beserta instrumen yang dipergunakan dengan baik. Sehingga dapat dikatan media merupakan perantara dari suatu proses komunikasi seperti seseorang menulis surat, maka media yang digunakan adalah kertas atau ketika menelepon menggunakan media telepon.

Berbeda dengan pemahaman tentang media sebagai "perantara" komunikasi pada umumnya, pemahaman akan media masa lebih dari sekedar "perantara komunikasi", akan tetapi media massa adalah media yang digunakan dalam komunikasi pres. Media massa atau juga dikenal sebagai Pres merupakan istilah yang digunakan pada tahun 1920-an untuk memperkenalkan jenis media yang secara khusus dirancang untuk masyarakat yang sangat luas (Tamburaka, 2013: 39).

Namun, media tidaklah mesti bersifat massa. Sebab, secara historis term media itu sendiri muncul dari suatu yang menjadi agen atau perantara dalam penyiaran pesan. Media pada dasarnya adalah bentuk dari medium; yang dalam bahasa Inggris medium merupakan bentuk singular form dari media. Konteks ini dijelaskan oleh Burton yang menyebutkan bahwa dalam memahami komunikasi diperlukan tiga hal, yakni objek (the objek), organ (the organ), dan medium (the medium). Praktek sederhana dari tiga hal ini adalah jam. Ketika alaram jam berbunyi, maka objeknya adalah jam dan pendengaran kita sebagai organ sehingga kita mengetahui waktu. Lalu, apa yang memerantarai jam dengan telinga kita? Tidak lain adalah bunyi!. Tanpa bunyi, maka kita tidak akan mengetahui waktu saat itu (Nasrullah, 2013: $5)$.

c. Literasi Media

Literasi media berasal dari bahasa Inggris yaitu Media Literacy, terdiri dari 
dua suku kata Media berarti tempat pertukaran pesan dan Literacy berarti melek, kemudian dikenal dengan istilah literasi media. Dalam hal ini literasi media merujuk kemampuan khalayak yang melek terhadap media dan pesan media massa dalam konteks komunikasi masa. Padanan kata istilah literasi media juga dikenal dengan istilah melek media pada dasarnya memiliki maksud sama (Tamburaka, 2013: 7).

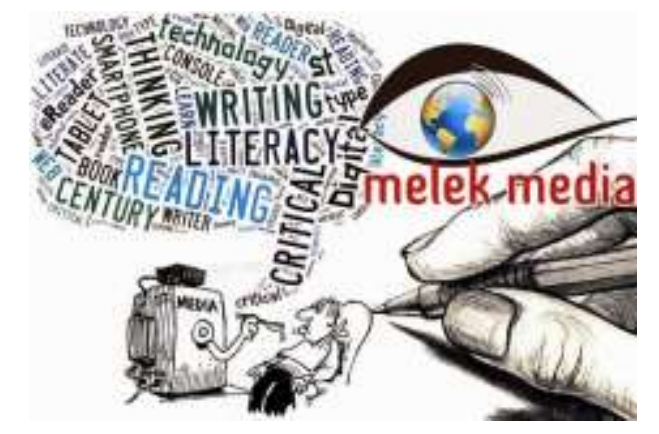

Gambar 4: Literasi Media

Untuk memahami istilah literasi media, terdapat beberapa lembaga terkait dengan literasi media telah menguraikan defenisi literasi media, antara lain:

Menerut Center For Media Literacy (CML), Media Literacy is a 21st century approach to education. It provides a framework to access, analyze, evaluate, create and participate with messages in a variety of forms - from print to video to the Internet. Media literacy builds an understanding of the role of media in society as well as essential skills of inquiry and self-expression necessary for citizens of a democracy (Center For Media http://www.medialit.org/medialiteracy-definition-and-more)
Media Literacy adalah pendekatan pendidikan abad 21. Ini menyediakan kerangka kerja untuk mengakses, menganalisis, mengevaluasi, membuat dan berpartisipasi dengan pesan dalam berbagai bentuk - dari cetak ke video ke Internet. Literasi media membangun pemahaman tentang peran media dalam masyarakat serta keterampilan penting penyelidikan dan ekspresi diri yang diperlukan untuk warga negara demokrasi.

Ifla Media and Information Literacy consist of the knowledge, the attitudes, and the sum of the skills needed to know when and what information is needed; where and how to obtain that information; how to evaluate it critically and organize it once it is found; and how to use it ethically. The concept extends beyond communication and information technologies to encompass learning, critical thinking, and interpretative skills across and beyond professional and educational boundaries. Media and Information Literacy includes all types of information resources: oral, print, and digital (Ifla, https://www.ifla.org/publications/iflamedia-and-information-literacy).

Literasi Media terdiri dari pengetahuan, sikap, dan jumlah keterampilan yang dibutuhkan untuk mengetahui kapan dan informasi apa yang dibutuhkan; di mana dan bagaimana mendapatkan informasi itu; bagaimana mengevaluasinya secara kritis dan mengaturnya begitu ditemukan; dan bagaimana menggunakannya dengan cara 
yang etis. Konsep ini melampaui komunikasi dan teknologi informasi untuk mencakup pembelajaran, pemikiran kritis, dan keterampilan interpretatif di seluruh dan di luar batas profesional dan pendidikan. Literasi media mencakup semua jenis sumber informasi: lisan, cetak, dan digital.

Dari dua definisi yang di kemukakan baik oleh Ifla maupun Center For Media Literacy (CML), dapat ditarik kesimpulan sederhana, literasi media yaitu suatu pengetahuan induvidu mengenai bagaimana suatu media berfungsi dalam khalayak masyarakat. Pada kurun waktu yang lama literasi media yang terbatas hanya pada kajian studi di perguruan tinggi kini sudah bergerak maju lebih terorganisasi atau terlembaga dan generasi selanjutnya dalam menyentuh pada upaya mempersiapkan kemampuan literasi media setiap induvidu di masa akan datang (Iriantara, 2009: 45).

\section{Masalah Perkembangan Literasi Media}

Di Indonesia

Perkembangan Literasi Media di Indonesia saat ini dapat dikatakan masih lambat oleh karena belum tersosialisasi dengan baik, di tengah masyarakat kondisi ini karena belum adanya kurikulum sekolah yang mengakomodasi pendidikan literasi media. Masalah-masalah sejumlah masalah yang dihadapi berkaitan dengan lambatnya perkembangan litersi media di Indonesia, yaitu:

\section{a. Tekanan dan Eforia Kebebasan Pers}

Sejarah buruk kebebasan pers di Indonesia turut andil dalam mempengaruhi minat masyarakat Indonesia dalam menjadi media massa sebagai ruang berekspresi. Pengaruh penjajahan belanda dan Jepang yang mengekang kesempatan pendidikan serta pengekangan kebebasan pers sejak Orde Baru menjadi bagian dari rendahnya partisipasi publik dalam memanfaatkan media massa berdemokrasi.

Begitu pula ketika Orde Baru runtuh dan keran kebebasan pers dibuka seluasluasnya, maka luang demokrasi di media menjadi lepas kendali. Banyaknya bermunculan yellow paper menunjukkan respons terhadap kebebasan pers yang begitu luas. Masalahnya adalah khalayak mengalami suatu leapfrog (lompatan) yang sangat jauh dari masyarakat yang terkekang dengan demokrasi di media menuju sebuah masyarakat media yang sangat demokratis. Sering kali demokrasi dalam media menjadi bermasalah karena lompatan yang begitu jauh, sedangkam masyarakat belum disiapkan menghadapi perubahan demokrasi, khususnya kebebasan dalm berekspresi di ruang 
media massa atau menaggapi akses dari beragam konten media saat ini (Tamburaka, 2013: 34).

\section{b. Konsumerisme media}

Ada kecendrugan sikap masyaraka Indonesia yang sangat konsumtif terhadap konten media, sehingga mempengaruhi sikap kritis terhadap media. Bagaimanapun harus diakui isu-isu penting di masyarakat banyak dipengaruhi dari informasi yang diperoleh melalui media namun tidak di imbangi dengan penyesuaian kebutuhan masyarakat akan media itu sendiri. Pengaruh budaya pop pada generasi muda menunjukkan gaya hidup dari luar yang didapatkan melalui media. Terapan media melalui iklan misalnya mempengaruhi fashion dan mode dari masyarakat Indonesia, namun sedikit sekali memikirkan tentang apa, mengapa, itu terjadi dan bagaimana menyikapi pesanpesan media secara proporsional.

c. Belum menjadi kurikulum resmi

Berbanding terbalik dengan beberapa negara-negara maju di barat, literasi media telah menjadi kurikulum resmi pendidikan dasar. Di Indonesia kegiatan literasi hanya sebagai pelengkap saja yang diperkenalkan oleh para penggiat dan aktivis literasi media. Dengan kata lain literasi media belum menjadi kebutuhan dari dunia pendidikan, sehingga wajar jika perkembangan literasi media sangat lambat di Indonesia. Kalaupun saat ini pendidikan literasi media hanya sebatas kajian tertulis artikel atau buku namun belum menjadi kurikulum resmi, setidaktidanya literasi media dapat dijadikan mata peajaran matan lokal pada tingkat pendidiakan dasar. Sedangakan pada tingakat menengah dan atas dapat dijadikan kegiatan ekstrakurikuler. Pada tingakatan peruruan tinggi dapat dijadikan mata kuliah penunjang wajib (Tamburaka, 2013: 35).

\section{METODE PENELITIAN}

Metode yang digunakan dalam penelitian ini adalah deskriptif kualitatif, drngan jenis penelitian studi kasus pada media social, yaitu peneliti ingin melihat gambaran dan fenomena status di media social sepeti Facebook yang di posting oleh khalayak melalui media sebagai pernyataan opini, tanggapan, pemberitahuan, atau representasi dari khalayak itu sendiri. Analisis data dalam penelitian ini menggunakan Teori Narartive Analysis. Sumber data dalam penelitian ini diperoleh dari postinganpostingan di media social yang terkait dengan informasi provokatif. Pendekatan yang digunakan dalam penelitian ini menggunakan pendekatan sosiologi Faucault. Teknik pengumpulan data dalam penelitian ini menggunakan studi dokumen dan teknik pengambilan sampel menggunakan Proposive Sampling yaitu 
memilih sampel berdasarkan karakteristik yang dianggap mewakili untuk dijadikan penelitian.

\section{PEMBAHASAN}

Status di media social seperti Facebook sebgai contoh kasus pada dasarnya diasumsikan sebagai sebuah narasi yang menceritakan makna-makna tertentu oleh karena status dikreasikan serta dipublikasikan oleh khalayak melalui media Siber sebagai peryantaan dari opini, tanggapan, pemberitahuan, atau representasi dari khalayak itu sendiri (Nasrullah, 2013: 35). Misalnya, kicauan akun Facebook atas nama jack yang memposting satu gambar dengan disertai narasi. Untuk melihat bagaimana posisi dari si pemilik akun terhadap suatu kasus atau peristiwa yang terjadi dan melihat posisi komentar-komentar terhadap berita tersebut, apakah pro atau kontra terhadap peristiwa dan atau sudut pandang yang di angkat oleh media (akun). Sehingga nantinya dapat melek terhadap status atas nama jack 24 tersebut. Dalam konteks ini, analisis narasi digunakan.

Postingan dengan nama akun jack, 24 November 2016 yang memposting satu gambar dengan disertai narasi atau keterangan. Jack menyoroti bukan soal pertemuannya, tetapi botol minuman warna hijau berada di atas meja. Meskipun ini postingan lama tapi jikalau terus di sebarkan hingga sekarang akan menjadi provokasi.

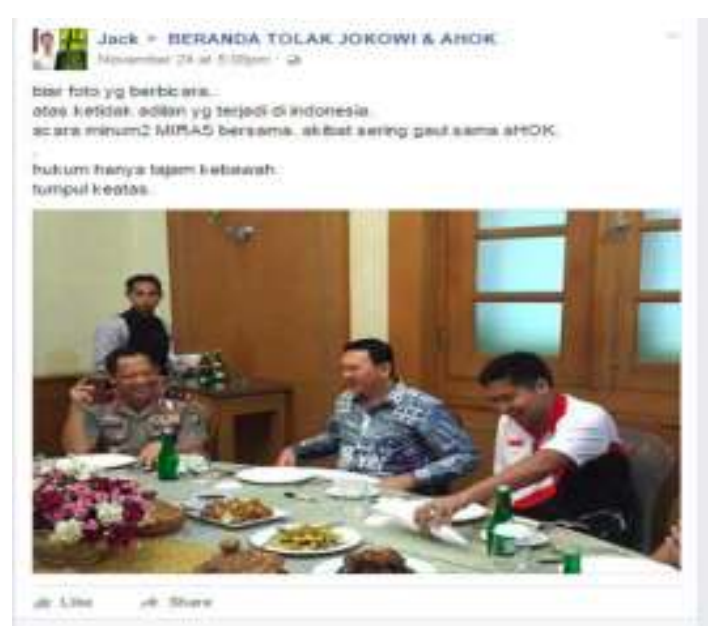

Gambar 5: Foto Dan Narasi Postingan Akun Jack

\section{Narasi:}

biar foto yg berbicara..

atas ketidak adilan yg terjadi di indonesia. acara minum2 MIRAS bersama. akibat sering gaul sama aHOK.

hukum hanya tajam kebawah tumpul keatas.

Krisis literasi terkhusus di media sosial menjadi sebab mengapa orang banyak terpedaya dengan suatu berita akan tetapi belum mengetahui kebenaran berita tersebut. Terlihat pada postingan jack pada akun facebooknya banyak yang 
mempercayainya tanpa membuktikan

kebenarannya, di antaranya:

Akhi Hilal Merah Ketika Manusia tampa mora Jadi penegak hukum...

Boy Khalid Liat si tito jd jongoss ahok. Ketawa lebayyy. Anjiriiittt

Rajh Grimmjow Jaeggerjaquez oh gini.. pantas saja

\section{Rochmat Sallam Mabok terus}

Dari hasil indentifikasi peneliti terhadap narasi dan gambar akun yang bernama jack tersebut, hasil dari penggabungan dari berbagai peristiwa menjadi satu alur cerita. Peneliti menemukan beberapa fakta:

Fakta 1:

Botol minuman di atas meja bukanlah miras (minuman keras) seperti yang dituduhkan melainkan air mineral merk Equil.

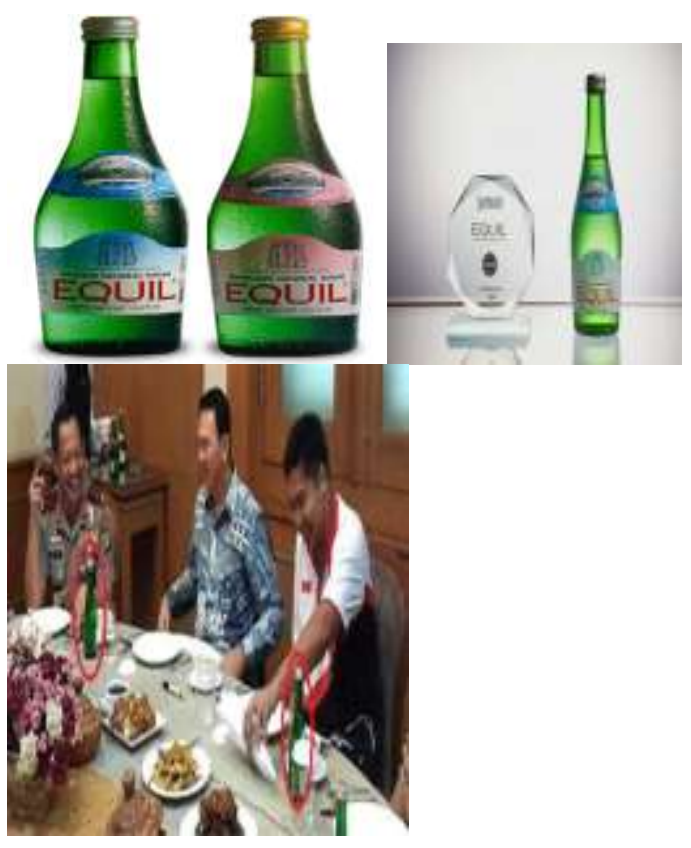

Gambar 6: Air Mineral Equil
Equil mungkin masih asing di telinga kebanyakan masyarakat Indonesia. Namun merk air mineral murni ini sudah cukup dikenal kalangan menengah atas dan ekspatriat. Equil kerap hadir di meja restoran fine dining, hotel bintang lima, hingga meja Istana Negara saat rapat kabinet. Jika melihat penampilan kemasannnya yang elegan, banyak orang akan mengira Equil adalah minuman impor. Namun Equil merupakan air mineral murni asli Indonesia produksi PT. Equilindo Lestari milik Morgen Sutanto (Surono http://intisari.gri).

Fakta 2:

Air mineral berbotol hijau ini (Equil) juga pernah muncul atau tampak di rapatrapat kabinet. Bahkan pada era Presiden SBY pun sandingannya Equil saat rapat (Bohang,

\section{https://tekno.kompas.com/read/2016/11/29}

/11011007).

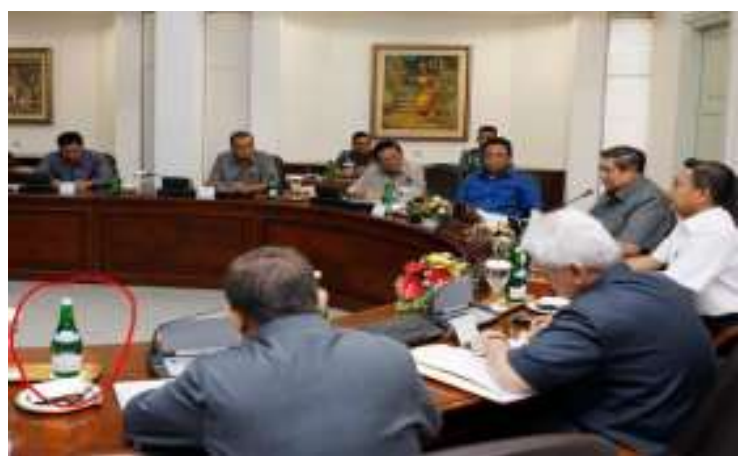

Gambar 7: Equil Pada Rapat Era SBY

Fakta 3:

Umumnya jika acara tersebut memang acara minum-minum keras (miras) 
bersama, makanan yang tersedia di atas meja buka makanan yang berat-berat tapi hanya berupa cemilan-cemilan atau makanan ringan Lazinya orang yang mengkonsumsi miras sandingannya adalah berupa cemilan-cemila.

Fakta 4:

Equil di jual bebas. Harga 1 botol equil setara 4 botol aqua terakhir peneliti lihat di tokopedia, 1 botol equil di hargai RP 19.000 rupiah. Artinya rata-rata harga satu botol equil dapat membeli empat botol Air mineral Aqua. Cukup mahal memang pantas equil merupakan minuman para pejabat.
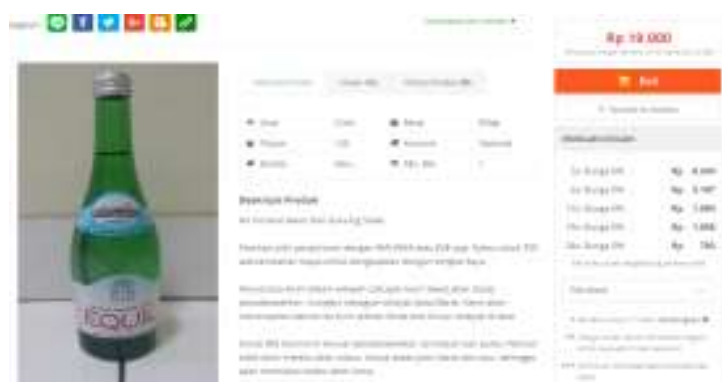

Gambar 8: Harga Terbaru Equil Di Tokopedia

Melihat dari fakta-fakta tersebut dapat di simpulkan bahwa postingan gambar yang di sertai keterangan oleh akun facebook yang bernama jack tersebut adalah postingan bohong (hoax) (Turnbackhoax). Sangat provokatif, penyebar kebencian dan merugikan pihak yang diberitakan dan terdapat unsur politik.
Berkaca pada hal tersebut, media literacy merupakan kemampuan untuk membawa keahlian berfikir kritis terhadap semua media, dari video musik, internet, hingga penempatan produk film dalam display virtual pada papan iklan. Media literacy mengajuakn pertanyaan tentang apa yang ada dan memperhatikan yang tidak ada. Media literacy merupakan insting yang dilatih dan dididik untuk mempertanyakan ada apa di balik produksi teks media, motif, uang, niali atau kepemilikan, dan menyadari bagaimana factor- factor tersebut mempengaruhi konten media.

Namun demikian, berpikir kritis melalui pendekatan media literacy saja kiranya belum cukup memadai untuk menjelaskan bagaimana teks media bekerja sebagai pencipta kebenaran atau sebaliknya dan berkuasa menyusun ilmu pengetahuan sebagai sesuatu yang normal dalam realitas social. Oleh karena itu, pemikiran Michel Foucault tentang kebenaran, kekuasaan dan ilmu pengetahuan menjadi relevan untuk diajukan. Tesis Foucault yang paling menarik untuk dikembangkan adalah hubungan antara kekuasaan dan ilmu pengetahuan (Syahputra, 2013: 176).

Pusat pemikiran Foucault terletak bukan pada apa itu kekuasaan, tetapi bagaimana kekuasaan itu bekerja dan 
dijalankan. Oleh sebab itu, Foucault memaknai kekuasaan bukan sebagai pemikiran seseorang terhadap sumbersumber atau asset kekuasaan tertentu yang bersifat material-struktural-institusional, melainkan kedaulatan yang diperoleh malalui penerapan disiplin dalam berbagai koherensi social. Focus perhatian Foucault bukan pada kekuasaan politik dalam hirarki pemerintahan atau struktur social, melainkan pada kekuasaan yang bersifat menyebar. Di mana saja ada aturan dan manusia memiliki koherensi antara satu dan lainnya dengan dunia, di tempat itulah kekuasaan itu bekerja. Perspektif baru inilah yang menghantarkan dialektika kekuasaan dan pengetahuan dalam media massa sebagai post media literacy.

Foucault menulis banyak buku lintas disiplin seperti sejarah, psikologi, sosiologi, gender, sastra, bahkan ilmu kedokteran. Kendati fokus studinya berbeda-beda, satu hal yang mempersatukan dan menarik perhatian Foucault adalah tentang kekuasaan dan pengetahuan dan bagaimana kedunya bekerja sama. Foucault tertarik pada pengetahuan akan manusia dan kekuasan yang berpengaruh atas manusia. Foucault meraguakan manusia memiliki pengetahuan tentang kebenatan mutlak (hakiki atau absolut). Oleh karena itu, menurutnya jika kebenaran mutlak tersebut disingkirkan, maka pengetahuan hanyalah apa yang dikumpulkan dan diputuskan benar oleh sekelompok orang melalui konvensi social-budaya atau lewat kesepakatan ilmiah, untuk membentuk kebenaran dibutuhkan tenaga sebagai kekuatan. Karena itulah, menurut Foucault, pengetauan itu adalah kekuasaan yan bersifat memaksa (Syahputra, 2013: 177-178).

Sedangkan jika melihat postingan atas nama akun Jack tersebut dari perspektif konflik kemungkinan pertama berada pada posisi superordinate dan menjadi alat untuk mewujudkan kepentingan yang memegang posisi tersebut. Praktik dominasi media dilakukan dengan mengendalikan isi media untuk menanamkan gagasan, pemikiran dan nilai-nilai yang digarapkan diikuti masyarakat sebagai posisi subordinat. Kelompok yang memiliki kepentingan ekonomi berusaha untuk melakukan berbagai komodifikasi terhadap isi media agar bisa melahirkan uang yang digali dari pihak terdominasi.

Dalam konteks ini maka kita tidak dapat membunyikannya dengan menggunakan pendekatan foucault, akan tetapi dengan meminjam pendekatan Karl Marx, yaitu kelompok media merupakan pemilik dan di pihak lain khalayak adalah kelompok pengguna sebagai buruh. Sebagai buruh maka ia melakukan aktivitas sebagai harapan kelompok 
superordinate. Disebut buruh karena jika khalayak mengikuti media dianggap sedang berkerja, yang hasil pekerjaannya berupa rating penonton atau dalam konteks politik media yang akan menghasilkan suara pemilik media (Rusyadi, 2015: 37).

Menurut aliran Marxis fundamentalis, memiliki pandangan bahwa factor ekonomi merupakan basis yang menentukan kehidupan supra suprastruktur yaitu ideologi, politik dan budaya. Kelas yang berkuasa yang memiliki alat-alat produksi material menguasai dan mengendalikan para pekerja. Pada saat yang sama mereka juga menguasai alatalat produksi mental sehingga masyarakat yang tidak memilikinya akan tunduk dan dikendalikan mereka. Media massa, dalam masyarakat kapitalis merupakan "alat produksi" yang dimiliki oleh pemilik media sebagai kelas yang berkuasa. Dalam konteks ini maka media sepenuhnya menjadi alat atau saluran untuk mendesiminasikan pandangan atau gagasan-gagasan kelas yang berkuasa melalui isi media dan makna yang dibawanya. Selain itu sebagai media komersial organisasi media harus memenuhi kebutuhan pengiklan untuk memproduksi isi media yang bisa memperoleh akses yang maksimal dari khalayaknya. Oleh karena itu untuk memenuhi kebutuhan tersebut media memproduksi program isi media yang mengandung seks dan kekerasan. Dengan demikian, dari sisi kelembagaan dan masyarakat menurut pandangan Maxis Fundamentalis, media merupakan bagian dari masyarakat kapitalis yang dikuasai oleh mereka yang memiliki sumberdaya ekonomi yang kuat sehingga memiliki kekuatan dalam mengendalikan media (Rusyadi, 2015: 38).

\section{KESIMPULAN}

Literasi media atau melek media merupakan keterampilan berfikir kritis untuk mempertanyakan kebenaran konten media. Memahami bahwa konten media pada satu sisi memberikan kita banyak informasi dan hiburan, akan tetapi pada sisi lain banyak konten media yang kurang bermanfaan. Literasi media sama sekali bukanlah gerakan anti-media. Justru merupakan tindakan yang kita lakukan untuk menjaga media agar tetap bisa menjalankan fungsinya di tengah masyarakat. Dengan melek media, media massa akan memiliki khalayak bukan konsumen yang pada gilirannya akan memengaruhi bagaimana seharusnya media menjalankan peranya. Bila media tetap memperlakukan khalayak sebagai konsumen maka media akan mendapat tekanan dari khalayak yang mempunyai kemampuan melek media. 
Kemudian agar dapat melek kebenaran suatu media (berita) bisa dengan melihat bagaimana narasi (status) berkembang. Misalnya status oleh akun facebook yang bernama jack tersebut, melihat dari fakta-fakta tersebut dapat di simpulkan bahwa postingan gambar yang di sertai keterangan adalah postingan bohong (hoax), terdapat makna yang tersimpkan pada postigan tersebut pertama sifatnya sangat provokatif, kedua mempunyai indikasi adu domba, ketiga mempunyai unsur penyebar kebencian dan keempat mempunyai niat untuk merugikan pihak yang diberitakan. Sehingga postingan tersebut dapat dikatakan mempunyai niat terselubung dengan penuh muatan politik dibalik pemilik akun tersebut (pelipat gandaan identitas).

\section{DAFTAR PUSTAKA}

Burton, Graeme. (1999). Media Dan Budaya Populer, Yogyakarta: Jalasutra

Erianto. (2013). Analisis Naratif DasarDasar Dan Penerapannya Dalam Analiss Teks Berita Media, Jakarta: Kencana

Iriantara, Yasol. (2009). Literasi Media Apa Mengapa Bagaimana, Bandung: Refika Offset

Ida, Rachmah. (2014). Metode Penelitian Studi Media Dan Kajian Budaya, Jakarta: Kencana

Nur Rochinah Tri Hastuti \& junaedi Fajar. (2013). Media Parenting:
Panduan Memilih Media Bagi Anak Di Era Informasi, Yogyakarta: Buku Literasi Yogyakarta

Nasrullah, Rulli. (2013). Cyber Media, Yogyakarta: IDEA Pres

Rusyadi, Udin. (2015). Kajian Media Isu Ideologis Dalam Perspektif, Teori Dan Metode, Jakarta: PT Raja Grafindo Persada

Syahputra, Iswadi. (2013). Rezim Media, Jakarta: PT Gramedia Putaka Utama

Tamburaka, Apriadi. (2013). Literasi Media Cerdas Bermedia Khalayak Media Massa, Jakarta: PT RajaGrafindo Persada. 